\title{
CLINICAL USES OF SEROMUCOID ESTIMATION
}

\author{
J. W. Keyser, M.Sc., Ph.D.(Lond.), F.R.I.C. \\ Reader in Chemical Pathology, University of Wales, at The Welsh National School of Medicine; \\ Honorary Consultant in Biochemistry, Cardiff United Hospitals.
}

From the Royal Infirmary, Cardiff

THE seromucoid* fraction of the plasma proteins comprises a group of glycoproteins-i.e., protein-carbohydrate complexes-characterized by their solubility in certain protein precipitants (perchloric, sulphosalicylic and trichloracetic acids) and by being not readily precipitated by heat. This fraction, which normally contains about $10 \%$ of the total protein-bound carbohydrate of the plasma and accounts for between $1 \%$ and $2 \%$ of the total plasma protein, may be estimated by precipitation from perchloric acid filtrates of serum by the addition of phosphotungstic acid, the protein or carbohydrate content of the precipitate being then determined (Winzler, Devor, Mehl and Smyth, I948). From its solubility properties and method of estimation it would appear that the seromucoid fraction is essentially identical with the socalled 'polypeptides', 'peptones' or 'albumoses' extensively studied by earlier workers (Wolff, I921; Hahn, I92: ; Cristol, 1922; Goiffon and Spaey, 1934; Fiessinger, 1934; and others). Indeed, the presence in human serum of a heatstable protein fraction soluble in acid proteinprecipitating agents was recognized as long ago as 1892 (Freund), and this fraction was subsequently studied by Zanetti (1897), Bywaters (1906, 1909), Rimington (1940) and others. An excellent historical account is given by Sonnet (1956).

Variations-usually increases-in the plasma concentration of seromucoid are found in many conditions. The purpose of this brief review is to outline the principal diagnostic uses to which the estimation of seromucoid has been applied. No attempt is made to present an exhaustive account of the numerous clinical and other studies that have been made. Greenspan

\footnotetext{
* Seromucoid is sometimes referred to as serum mucoprotein. The term mucoprotein is, however, now generally used to denote a different class of compounds in which a protein is combined with an acid mucopolysaccharide (e.g., hyaluronic acid, chondroitin sulphate). Small amounts of acid mucopolysaccharides are present in the serum.
}

(I955) has suggested that the concentration $\vec{f}$ seromucoid is the resultant of an extremely labile interplay between two groups of non specific factors: on the one hand tissue responses. associated with inflammation, degeneration of trauma, which raise the seromucoid concen tration, and on the other hand hepatic or endo $=$ crine insufficiency, which are associated with low concentrations. The seromucoid-enhancing faco tors usually predominate.

It must be emphasized that the seromucoid fraction, as prepared by treatment of serum with perchloric acid, contains a number of proteins, among which various workers håg identified orosomucoid ( $\alpha_{1}$-acid glycoprotein), 3 S $\alpha_{1}$-glycoprotein and haptoglobin, as well several others (Winzler, I960; de Vaux St. Cyr 1960). Since the individual components of the seromucoid fraction contain differing amount of carbohydrate and may vary independentl 9 in their concentrations, it follows that estimation $\vec{B}$ based on measurement of the protein content of the fraction will not necessarily agree witl? those based on measurement of its carbohydrate. content. Variations in the carbohydrate/proteing ratio have been stated to be of diagnostic value (see below).

It may be expected that specific determination of the individual glycoproteins, for example by immunochemical methods (cf. Gell, 1957; Easton Hardwicke and Whitehead, 1962), will in the future provide more useful information than has been obtained by the methods used hitherto

\section{Diagnosis of Cancer}

Some of the most striking increases in plasman seromucoid concentration are found in manys types of cancer (Winzler and Smyth, 1948). In a series of 114 cases studied by Lockey, Anderson and Maclagan (1956), the highest values weres recorded in patients with widely disseminated cancer; results were particularly striking in the lymphomata, while in malignant disease confined to bone very little elevation was found; and 
TABLE

Some Conditions in which Elevated Blood SeromuCoId CONCENTRATIONS ARE COMMONLY Found.

Cancer

Rheumatoid arthritis

Rheumatic fever

Pneumonia

Acute infections

Trauma (burns, fractures)

Myocardial infarction
Winzler and Smyth, 1948

Shetlar, Payne Bullock Patrick, Hellbaum and Ishmael, 1953 .

Kelley, Good and M'Quarrie, I950; Kelley, Adams and Good, 1953 .

Turner, Schaffner, Eshbaugh and de la Huerga, 1953

Winzler and Smyth, 1948

Greenspan, 1955

Keyser, 1952

Simkin, Bergman and Prinzmetal, 1949

other types of cancer occupied an intermediate position. However, comparable increases are found also in many other conditions (see Table); and this, together with the fact that normal seromucoid concentrations are found in some patients with cancer, especially when the disease is not far advanced, has led to the estimation's being regarded as of little practical value for detecting cancer (Winzler and Smyth, I948; Henry, Berkman, Little and Winzler, I95I; Rhees, Ellerbrook and Lippincott, 1954). This view is disputed by Cameron, Campbell and Plenderleith (r96ra), who point out that most non-malignant conditions associated with a high concentration of plasma seromucoid are easily recognized and do not commonly enter into the diagnosis of cancer; consequently the test may often provide considerable diagnostic and prognostic information. In a series of 206 patients in whom malignancy was established, either histologically or at operation, or on the basis of clinical and radiological evidence, the majority (about 90\%) had elevated seromucoid concentrations at the time of their first attendance at hospital; of those patients with normal concentrations, the majority had small tumours which had attracted attention at an early stage because of their superficial situation, and the diagnosis was apparent on clinical grounds. Normal concentrations are commonly found, for example, in patients with cancer of the breast (cf. Shetlar, Foster, Kelly, Shetlar, Bryan and Everett, 1949). There remained another group of patients in whom the test failed to detect cancer: these patients either had tumours of border-line malignancy, with little or no invasiveness, or else had small, early tumours of internal organs. In such cases, if other investigations prove unhelpful, repeated estimations of seromucoid at intervals may provide the earliest clue to the diagnosis (Cameron, Campbell and Plenderleith, I96ra).
Occasionally even patients with advanced cancer may show no rise in seromucoid concentration. This was so with two patients in the terminal stages of gastric cancer, and Cameron and his co-authors suggest that the failure of the seromucoid concentration to increase in these two cases may be attributed to the presence of extensive hepatic metastases. This explanation should be accepted with reserve: in published series (Greenspan, Tepper, Terry and Schoenbach, 1952; Greenspan and Dreiling, 1953; Greenspan, 1954; Keyser, Payne and Stephens, 1962) the great majority of patients with hepatic metastases had elevated concentrations of seromucoid, only a few falling within the normal range. Indeed, some of the highest values found were in this group of patients. Nevertheless, it may well be that a certain minimal amount of normal liver tissue is required to produce elevated concentrations of seromucoid.

Seromucoid estimations can also be used to assess response to treatment, and in prognosis. Thus, Cameron and others found that successful treatment by radiotherapy, or with hormones or cytotoxic agents, is associated with a return of seromucoid concentrations to normal (cf.' Keyser, I954); and in patients treated surgically a sustained return of seromucoid concentrations to normal is an indication of adequate resection and a favourable prognosis (Cameron and others, r96ra).

In interpreting the significance of a raised concentration of seromucoid it is particularly important to bear in mind the influence of infection (see Table).

\section{Selection of Patients for Endocrine Ablation}

In the treatment of advanced cancer of the breast by endocrine ablation, remission is achieved in only a minority of patients, and when the employment of such procedures is considered the patient is usually in a feeble state. Burnett, McAllister and Shields (1963) therefore sought methods to help in the selection of patients likely to benefit from operation. In an investigation of $4 \mathrm{I}$ patients who underwent endocrine ablation for advanced cancer of the breast they found that very high concentrations of serum glycoproteins were associated with a poor prognosis. They suggest that patients with serum glycoprotein concentrations above certain limits are unlikely to benefit from endocrine ablation. Four serum glycoprotein 'indices' were measured, viz. total protein-bound carbohydrate, seromucoid-carbohydrate, seromucoid-'tyrosine' (a measure of the seromucoidprotein) and seromucoid estimated turbidimetrically. Of these, a knowledge of the seromucoid- 
carbohydrate concentration was found to be the most useful.

\section{Differential Diagnosis of Jaundice}

A decreased concentration of seromucoid was reported by Greenspan and his co-workers in hepatocellular disease due to infective hepatitis, homologous serum hepatitis, toxic (chemically induced) hepatitis, and portal cirrhosis (Greenspan, Tepper, Terry and Schoenbach, I952; Greenspan and Dreiling, 1953; Greenspan, 1954). Thus the incidence of a decreased seromucoid concentration was more than $80 \%$ in 83 patients with infective or homologous serum hepatitis and more than $70 \%$ in 94 patients with portal cirrhosis, whereas less than $3 \%$ of 146 patients with various forms of obstructive disease of the biliary tract had decreased concentrations (Greenspan, 1954). Most of the patients in the hepatitisportal cirrhosis group that had normal or high seromucoid concentrations were suffering from coexistent septicaemia, pneumonia, peritonitis, tuberculosis, hepatoma or ulcerative colitis. All of these are conditions in which elevated seromucoid concentrations are found. As a result of their studies Greenspan and his collaborators proposed the estimation of the seromucoid concentration as a means of distinguishing between 'medical' and 'surgical' jaundice.

Greenspan and his collaborators also measured the ratio of 'polysaccharide' to protein in the seromucoid fraction. While patients with uncomplicated infective hepatitis, homologous serum hepatitis or portal cirrhosis had an increased 'polysaccharide'/protein ratio, patients with neoplastic infiltration of the liver, associated with hepatomegaly, had essentially normal ratios; and measurement of these ratios, as well as of the actual seromucoid (protein) concentration, was thought to be clinically useful in the differentiation of neoplastic from primary parenchymatous disease of the liver (Greenspan, Lehman, Graff and Schoenbach, r95I; Greenspan, Tepper and Schoenbach, 195I; Greenspan and others, 1952).

Mandel, Gorsuch and Cooper (1955) found a somewhat lower incidence of subnormal seromucoid concentrations both in viral hepatitis and in alcoholic cirrhosis $(39 \%$ and $15 \%$, respectively; increasing to $50 \%$ and $43 \%$ when patients with complicating extrahepatic disease processes were excluded). No subnormal values were found in biliary obstruction. Mandel and his collaborators concluded that a definite diagnostic value could be attached only to the finding of a subnormal concentration of seromucoid; in association with jaundice or hepatomegaly, or both, and in the absence of a nephrotic syndrome (Kelley, Good, Glick and Ochs, r950), of excessive hyperglobulinæmia and, perhaps, of certain endocrinopathies (Greenspan, 1954), this was almost pathognomonic of hepato- $c$ cellular disease. On the other hand the finding of a normal or elevated concentration was of $\stackrel{\rho}{?}$ very limited value.

Varay and Masson (1960) confirmed the $\frac{\bar{C}}{0}$ tendency for the seromucoid concentration to $\frac{\bar{s}}{5}$ be below average in hepatitis, though inspection $\stackrel{\otimes}{\Omega}$ of their results suggests that in fact only two out of 24 patients with this disease had con- $\rightarrow$ centrations definitely below the normal range. Raised concentrations were found in patients $\vec{\omega}$ with obstructive jaundice, whether the obstruc- $\stackrel{\circ}{\circ}$ tion was extra- or intra-hepatic. Results in 8 cirrhosis were variable: it would appear that 3 . infections were responsible for high values in $\overrightarrow{0}$ many cases. Very high values were found in five patients with cancer of the liver.

Cameron, Campbell and Plenderleith (196rb) $\vec{\infty}$ reported essentially normal values in patients with + hepatic cirrhosis, and considerable overlapping of the normal range in patients with infective $\rightarrow$ hepatitis. Keyser and others (1962) confirmed $\frac{D}{0}$ the existence of raised seromucoid concentrations in most patients with obstructive jaundice $\vec{\oplus}$ and especially in most patients with obstructio due to carcinoma or with secondary deposits of carcinoma in the liver; in agreement with Mandeे and his colleagues, only a minority of patients with hepatocellular disease were found to have a lowered seromucoid concentration.

Shields, McAllister and Burnett (1963), who made a similar study, concluded that estimation of the seromucoid concentration was of great value in distinguishing hepatic from post-hepatic jaundice. Indeed, they found the estimation of seromucoid-'tyrosine' more useful in differential diagnosis than the conventional tests, especially in the absence of current extra-hepatic disease.

The estimation of seromucoid would seem, then, to have a place in the differential diagnosis of hepatobiliary disease, provided that the results 0 are interpreted cautiously, with due regard to the many factors that may influence the concentration of this fraction. Because of this limitation it is not to be expected that the estima- or tion will help decisively in more than a minority $N$ of cases.

According to Greenspan, 'intraglobulin fractional analysis' by a battery of four determinationsseromucoid, 'acid-precipitable globulin turbidity' (a measure of $\alpha_{2}$ plus $\beta$-globulins), zinc sulphate $\stackrel{\infty}{\rightarrow}$ turbidity and total protein-bound hexose-com- $\square$ pares favourably with the cephalin flocculation $\overline{0}$ test, estimation of alkaline phosphatase and other $\stackrel{\mathbb{D}}{\mathbb{P}}$ established aids in the differential diagnosis of $\underset{\mathbb{Q}}{\mathbb{Q}}$ 
jaundice (Greenspan, 1956; Greenspan and Dreiling, 1957).

Cameron, Campbell and Plenderleith (1962) used the seromucoid estimation to help in the investigation of upper gastrointestinal hæmorrhage. They concluded that œsophageal varices, peptic ulcer and carcinoma of the stomach tended to be associated with low, normal and high seromucoid concentrations respectively.

\section{Assessment of Activity in Various Diseases}

A number of investigators have correlated seromucoid concentration with the degree of clinical activity in various diseases. For example, Turner, Schaffner, Eshbaugh and de la Huerga (1953) found that a high seromucoid concentration in the presence of known pulmonary tuberculosis strongly suggests that the disease is far advanced, and extremely high values were thought to indicate a very poor prognosis. Shetlar and Payne (1958) found a significant correlation between the seromucoid (and also total glycoprotein) concentration and the degree of inflammatory activity in patients with rheumatoid arthritis. Patients with 'psychogenic rheumatism' had normal concentrations (Shetlar, Payne, Bullock, Patrick, Hellbaum and Ishmael, 1953). In rheumatic fever also the seromucoid concentration is considerably increased when the disease is active, but only slightly increased when it is not (Shetlar, 1958). In patients with myopathies, motor neurone disease and allied conditions those patients who appeared clinically to be actively wasting showed the highest seromucoid concentrations (Keyser, Jenkins, Lloyd, Pallis and Sanders, 1957). (This last investigation was undertaken not so much with the object of seeking aids to diagnosis as to obtain evidence for an association between increased glycoprotein concentrations and tissue breakdown (cf. Seibert, Seibert, Atno and Campbell, 1947).)

More recently, a raised seromucoid concentration has been found to be associated with other evidence of clinical activity of the intestinal lesion in patients with regional ileitis or ulcerative colitis (Cooke, Fowler, Cox, Gaddie and Meynell, 1958). The use of the seromucoid estimation in gastroenterology to detect and obtain an estimate of the degree of activity in new patients, and also to check response to therapy, and in long-term follow-up, is summarized by Fowler and Cooke (196r).

Other applications of seromucoid estimation, such as the investigation of renal disease and the diagnosis of myeloma, are described by Varay and Masson (1960). Sonnet (1956) discusses in detail the findings in a number of diseases, particularly the paraproteinæmias.

\section{'Mucoproteins' of Ascitic, Pleural and Cere- brospinal Fluids}

A number of investigators have examined other body fluids besides blood for their content of 'mucoprotein' (i.e., perchloric acid-soluble, phosphotungstic acid-precipitable proteins) in various diseases. Taipale and Hokkanen (1956) studied the mucoprotein concentration of ascitic and pleural fluids. The concentration in ascitic fluid was lowest in patients with liver cirrhosis; the highest values were found in fluids from patients with malignant tumours; patients with congestive heart failure occupied an intermediate position, and in this group the lowest values were found in patients with cardiac cirrhosis. Taipale and Hokkanen concluded that determination of the mucoprotein of the ascitic fluid is of diagnostic significance, the corresponding serum concentrations in these three groups showing noticeably smaller differences. The findings of Spak (1960) and of Lopez and Kozma (196I) also suggest that the estimation of this fraction in ascitic fluid may be useful in diagnosis. Estimation of the mucoprotein in pleural fluid, however, did not appear to have any diagnostic value (Taipale and Hokkanen).

Biserte, Havez, Guerrin, Laturaze and Hayem (I96I) investigated the electrophoretic and immunoelectrophoretic properties of ascitic fluids of different types (neoplastic, cirrhotic and cardiac). Orosomucoid, which is the major constituent of perchloric acid filtrates, was present in all the fluids examined, but was found in the greatest concentration in neoplastic ascitic fluids. Haptoglobin was found always in neoplastic fluids but in only a few fluids of cirrhotic origin. One glycoprotein, designated seromucoid $\beta_{1}$ ( $\beta_{1 \mathrm{~B}}$-globulin), was found to be characteristic of exudates of cancerous origin; like haptoglobin, it was often absent from fluids of cirrhotic origin. All these glycoproteins are soluble in perchloric acid $(0.6-0.8 \mathrm{M})$.

Roboz, Apostol, Luft and Hess (1957) reported high concentrations of mucoprotein in the cerebrospinal fluid of patients with tumours of the central nervous system; and according to Zlotnick, Weisenberg and Chowers (1959) a high concentration of mucoprotein in the cerebrospinal fluid suggests the presence of a tumour of the central nervous system in cases where an acute infection or an abscess can be ruled out. However, Silverstein and Greenspan (1959) could not detect mucoprotein in the cerebrospinal fluid of about two-thirds of the patients they investigated; 
although there did appear to be a higher incidence of c.s.f. mucoprotein in patients with neoplasms of the central nervous system, or with proven occlusive cerebral vascular disease, the finding of mucoprotein in the fluid of patients without neurological disease (in the same frequency and amounts as in the whole group of patients with neurological disease) appeared to limit the value of the investigation.

Bauer (1957) has analysed the perchloric acid-soluble, phosphotungstic acid-precipitable fraction of cerebrospinal fluid and has found that it differs from seromucoid of blood in respect of both carbohydrate content and electrophoret mobility.

\section{Summary}

The clinical applications of seromucoid estima tion, especially in the diagnosis of cancer, the selection of patients for endocrine ablation, the differential diagnosis of jaundice, and the assessment of activity in various diseases, af briefly described.

I am grateful to Professor J. Gough, M.D., and MP. R. Shields, M.B., Ch.B., F.R.C.S., for their helpfï criticisms and suggestions.

\section{REFERENCES}

BAuER, H. (1957): Zur Frage der Identität der Liquorproteine mit dem Eiweisskörpern des Blutserums. III. D落 Mucoproteine des Liquors, Dtsch. Z. Nervenheilk., 176, 126.

Biserte, G., Havez, R., Guerrin, F., LAturaze, J., and Hayem, A. (I96r): Caractéristiques électrophorétiques ể immunologiques des globulines de liquides d'ascite d'origine néoplasique, Clin. chim. Acta., 6, 833.

Burnet,, W., McAllister, R. A., and ShieldS, R. (1963): The Use of Serum Glycoprotein Levels in the Selectiond of Patients with Advanced Breast Cancer for Endocrine Surgery, Scot. med. F., 8, 197.

Bywaters, H. W. (1906): On the Presence and Amount of 'Seromucoid' in Blood, $\mathscr{f}$. Physiol., 35, vi.

(1909): UUber Seromucoid, Biochem. Zeitschr., 15, 322.

Cameron, E., Campbell, A., and Plenderleith, W. (r96ra): Seromucoid in the Diagnosis of Cancer, Scot. med. F 6, 301 .

$\longrightarrow, \frac{6}{-},-(196 \mathrm{rb})$ : Seromucoid in the Diagnosis of Jaundice, Ibid., 6, 308.

$-,-1, \quad(1962)$ : The Role of Seromucoid Estimations in the Investigation of Hæmatemesis, Gut, 3, 260

Cooke, W. T., Fowler, D. I., Cox, E. V., Gaddie, R., and Meynell, M. J. (1958): The Clinical Significancę o Seromucoids in Regional Ileitis and Ulcerative Colitis, Gastroenterology, 34, 910.

Cristol, P. (r935): A propos d'articles récents sur l'intoxication par les polypeptides, Presse méd., 43, r ro7.

DE VAUX ST. CYR, CH. (1960): Etudes immuno-électrophorétiques des protéines perchlorosolubles des sérums humån normaux et pathologiques: identification de certaines fractions, Prot. Biol. Fluids, Proc. 7th Colloq., Bruges, $\mathrm{r} 95$ p. 48.

Easton, J. A., Hardwicke, J., and Whitehead, P. H. (1962): The Estimation of Two Alpha 1 Glycoproteins (Oroso̊ mucoid and another Alpha ${ }_{1}$ Acid Glycoprotein) in Health and Disease, $\mathcal{F}$. clin. Path., 15,585 .

Fiessinger, N. (1934): L'intoxication par les polypeptides, Presse méd., 42, i 787.

Fowler, D. I., and Cooke, W. T. (I96I): The Value of Seromucoid Determination in Gastroenterology, Proc. As clin. Biochemists, $\mathbf{1}, 73$.

Freund, E. (1892): Ueber das Vorkommen von Thierischem Gummi in normalem Blute, Zentralbl. Physiol., 6, 345

Gell, P. G. H. (1957): The Estimation of the Individual Human Serum Proteins by an Immunological Methoth f. clin. Path., ro, 67.

Golffon, R., and SPAEY, J. (1934): Méthode colorimétrique de mesure des polypeptides du sérum, C. R. Soc. Biog (Paris), II5, 7 I 1 .

GreENSPAN, E. M. (1954): Survey of Clinical Significance of Serum Mucoprotein Level, A.M.A. Arch. intern. Med 93,863 .

93, 863.: Clinical Significance of Serum Mucoproteins, Adv. intern. Med., 7, ror.

(1956): A Clinical Survey of Globulin Distribution Patterns Determined by Simple In Vitro Laboratory Methods f. Mt. Sinai Hosp., 23, 172.

Jaundice, A.M.A. Arch. intern. Med., 9r, 474.

(1957): Intraglobulin Fractional Analysis as an Aid in the Differentiation of Medical from Surgical Jaundice ,Gastroenterology, 32, 500.

'Lehman, I., GrafF, M. M., and Schoenbach, E. B. (I95 I): A Comparative Study of the Serum Glycoprotein in Patients with Parenchymatous Hepatic Disease or Metastatic Neoplasia, Cancer, 4, 972.

, Tepper, B., and Schoenbach, E. B. (195 I): The Estimation of Serum Mucoprotein as an Aid in the Differentia tion of Neoplastic from Primary Liver Disease, Proc. Nat. Meeting Amer. Fed. clin. Res., Abstract 59.

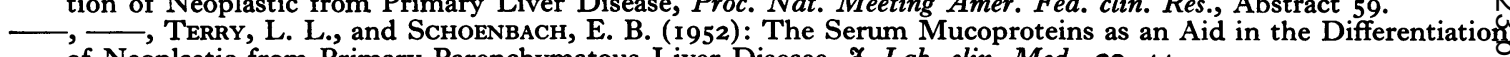
of Neoplastic from Primary Parenchymatous Liver Disease, F. Lab. clin. Med., 39, 44.

HAHN, A. (1921): Der Dopplestickstoff, ein Diagnostikum für endogenen Eiweisszerfall, insbesondere für okkulte eitrige Prozesse, Biochem. Z., 121, 262.

Henry, R. J., Berkman, S., LitTle, M. S., and Winzler, R. J. (I95I): Inaccuracy of Four Chemical Procedures a $\$$ Diagnostic Tests for Cancer, F. Amer. med. Ass., 147, 37.

Kelley, V. C., Good, R. A., Glick, D., and OcHs, M. J. (1950): Mucolytic Enzyme Systems. XI. Hyaluronidase Inhibitor and Serum Mucoproteins in Patients with Lipoid Nephrosis and Acute Glomerulonephritis, $\mathcal{F}$. clin Invest., 29, 1500.

—, AdAMs, F. H., and Good, R. A. (1953): Serum Mucoproteins in Patients with Rheumatic Fever, Pediatrics, 12, 60韧 
Good, R. A., and M'Quarrie, I. (1950): Serum Mucoproteins in Children in Health and Disease with Special Reference to Rheumatic Fever, Ibid., 5, 824 .

Keyser, J. W. (1952): Blood Serum Protein-bound Carbohydrate after Injury, F. clin. Path., 5, r94. (I954): Effect of Nitrogen Mustard or X-or Radium-irradiation Treatment on the Level of Blood Serum Proteinbound Carbohydrate (Polysaccharide) in Patients with Neoplastic Diseases, Brit. F. Cancer, 8, 238.

, Payne, R. B., and Stephens, B. T. (r962): Laboratory Tests in the Differential Diagnosis of Liver Disease: Report on Two Procedures, Clin. Chem., 8, 270.

—, Jenkins, W. J., Lloyd, G. H. T., Pallis, C., and Sanders, P. G. (1957): Serum Proteins and Protein-bound Carbohydrate in Relation to Tissue Breakdown and Regeneration, Biochem. F.; 65, $37 \mathrm{P}$.

Lockey, E., Anderson, A. J., and Maclagan, N. F. (1956): Urine and Serum Mucoproteins in Cancer and Other Diseases, Brit. F. Cancer, ro, 209.

Lopez, J. E., and Kozma, C. (i96r): Determination of the Perchloric Acid-soluble, Phosphotungstic Acid-insoluble Fraction (Seromucoid) in Ascitic Fluid and Serum, G.E.N. (Caracas), 16, 105 (cited by Chem. Abs., 1962, 56, 10740).

Mandel, E. E., Gorsuch, T. L., and Cooper, G. E. (1955): Seromucoid in Hepatobiliary Disease, Clin. Chem., r, 22 I.

Rhees, M. C., Ellerbrook, L. D., and LippincotT, S. W. (I954): Studies of Various Tests for Malignant Neoplastic Diseases. VIII. The Determination of Plasma or Serum Mucoprotein, Amer. F. Clin. Path., $24,774$.

Rimington, C. (1940): Seromucoid and the Bound Carbohydrate of the Serum Proteins, Biochem. F., 34, 931.

Roboz, E., Apostol, R. R., Luft, A. M., and Hess, W. C. (1957): Determination of the Carbohydrates in the Glycoproteins and Mucoproteins of Cerebrospinal Fluid, f. Lab. clin. Med., 49, 796.

Seibert, F. B., Seibert, M. V., Atno, A. J., and Campbell, H. W. (1947): Variation in Protein and Polysaccharide Content of Sera in the Chronic Diseases, Tuberculosis, Sarcoidosis, and Carcinoma, F. clin. Invest., 26, 90.

Shetlar, M. R. (1958): The Serum Glycoprotein as an Indication of Disease Process, F. Oklahoma State Med. Ass., 323. , and PAYNe, R. W. (1958): Objective Evaluation of Patients with Rheumatic Diseases. IV. Comparison of the Diphenylamine Reaction (DPA) with Serum Glycoprotein and Seromucoid Levels, F. Lab. clin. Med., 51, 588. , Foster, J. V., Kelly, K. H., Shetlar, C. L., Bryan, R. S., and EveretT, M. R. (I949): The Serum Polysaccharide Level in Malignancy and in Other Pathological Conditions, Cancer Res., 9, 515.

—, Payne, R. W., Bullock, J. A., Patrick, D. R., Hellbaum, A. A., and Ishmael, W. K. (i953): Comparative Studies of Serum Polysaccharides in Rheumatoid Arthritis and Degenerative Joint Disease, $\mathcal{F}$. clin. Invest., 32, 1208.

Shields, R., McAllister, R. A., and Burnett, W. (1963): Evaluation of Serum Glycoproteins in the Differential Diagnosis of Jaundice, Scot. med. $\mathfrak{F} ., 8,185$.

Silverstein, A., and Greenspan, E. M. (1959): Mucoprotein Content of Cerebrospinal Fluid, Confin. neurol. (Basel), I9, 306.

Simkin, B., Bergman, H. C., and Prinzmetal, M. (r949): Quantitative Changes in a Serum Mucoprotein following the Occurrence of Myocardial Infarction, Amer. F. Med., 6, 734 .

Sonnet, J. (I956): 'Les Glycoprotéines Sériques à l'Etat Normal et Pathologique'. Brussels: Editions Arscia.

Spak, I. (1960): Clinical Value of Chemical Analyses of Ascites, Acta chir. Scand., Suppl. 261, ro.

Taipale, E., and Hokkanen, E. (1956): The Mucoprotein Levels of the Ascitic and Pleural Fluids and Their Clinical Significance, Acta med. Scand., $155,113$.

Turner, G. C., Schaffner, F., Eshbaugh, D. E., and de la Huerga, J. (1953): Serum Mucoproteins in Pulmonary Tuberculosis, Dis. Chest., 23, 154 .

VARAy, A., and Masson, M. (1960): Les mucoprotéines du sérum. Intérêt pratique de leur détermination, Presse méd., 68, 1323.

WinZler, R. J. (i 960): 'Glycoproteins', in 'The Plasma Proteins', ed. F. W. Putnam, Vol. I. New York and London: Academic Press.

, Devor, A. W., Mehl, J. W., and Smyth, I. M. (1948): Studies on the Mucoproteins of Human Plasma. I. Determination and Isolation, $\mathcal{F}$. clin. Invest., 27, 609.

-, and Smyth, I. M. (1948): Studies on the Mucoproteins of Human Plasma. II. Plasma Mucoprotein Levels in Cancer Patients, Ibid., 27, 6r7.

Wolff, E. (192I): Sur l'albumosémie à l'état physiologique et pathologique, Ann. Méd., 10, 185.

ZanetTi, C. (1897): Ann. Farmacoter. Chim., 26, 529 (cited by Rimington, 1940).

Zlotnick, A., Weisenberg, E., and Chowers, I. (1959): Mucoproteins of Cerebrospinal Fluid and Blood in Neurologic Disorders, F. Lab. clin. Med., 54, 207. 